\title{
Biology and Control of Horse Purslane and Common Purslane in Sugarcane ${ }^{1}$
}

\author{
Dennis Calvin Odero, Ron Rice, and Les Baucum²
}

Horse purslane and common purslane are broadleaf weeds associated with sugarcane fields in muck (organic) and mineral soils of South Florida. Growers often confuse these two weed species with each other. However, these two species have distinct phylogenetic (evolutionary) and morphological differences.

\section{Horse Purslane}

Horse purslane (Trianthema portulacastrum) is a muchbranched, fleshy, succulent, prostrate annual weed in the Aizoaceae (fig-marigold) family. Originally native to South Africa, it is widely distributed in the United States and can be found from Florida to Texas and California, and north to New Jersey, Missouri, and Oklahoma (USDA-NRCS 2012). In Florida, it is widely distributed in Palm Beach, Monroe, Manatee, and Seminole Counties. Horse purslane's prostrate growth and profuse branching help it quickly cover the soil surface and form a green carpet in open cultivated fields and disturbed areas.

\section{Seedling}

Seedlings are erect but soon become prostrate. Cotyledons are linear and green. The leaves are opposite, unequal, and hairless, with a long stalked leaf in front of a small stalkless leaf. Leaf stalks are present in all subsequent leaves. Leaf blades are broadest and rounded at the tip, but then taper toward the base (the long-stalked leaf is often notched at the tip). Leaves are encircled by a purplish color. Stems are maroon-purple, hairy, and erect (Figure 1).

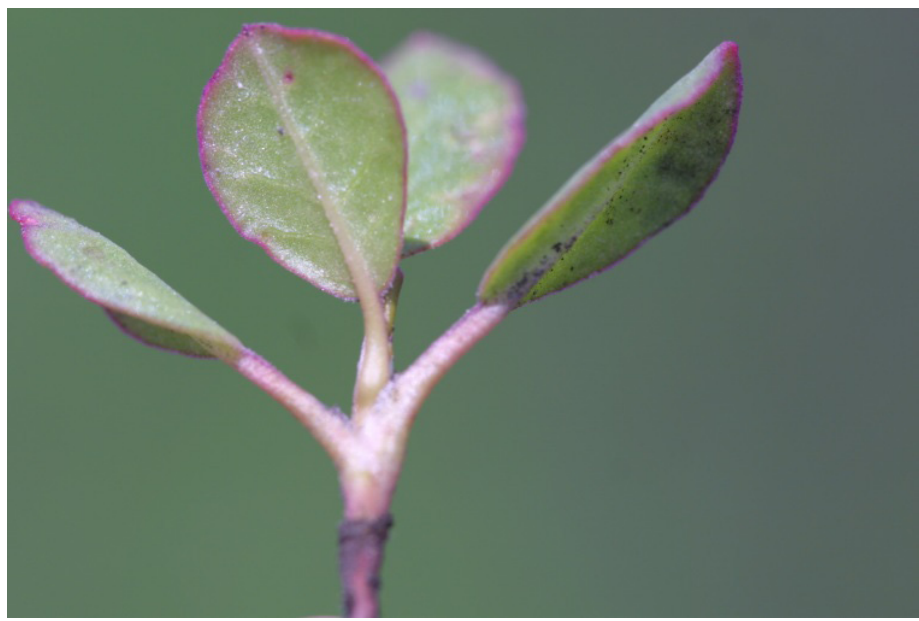

Figure 1. Seedling of horse purslane.

Credits: D. C. Odero

\section{Mature Plant}

Stems are weakly branched to erect, but later prostrate. The round, solid stems can grow up to 7 feet long, and are

1. This document is SS-AGR-368, one of a series of the Agronomy Department, Florida Cooperative Extension Service, Institute of Food and Agricultural Sciences, University of Florida. This publication is a part of the Florida Sugarcane Handbook. For more information, contact the editor of the Sugarcane Handbook, Ronald W. Rice (rwr@ufl.edu). Original publication date January 2013. Please visit the EDIS website at http://edis.ifas.ufl.edu.

2. Dennis Calvin Odero, assistant professor, Agronomy Department, Everglades Research and Education Center, Belle Glade, FL; Ron Rice, Extension agent, Palm Beach County, Belle Glade, FL; and Les Baucum, Extension agent, Hendry County, LaBelle, FL; Florida Cooperative Extension Service, Institute of Food and Agricultural Sciences, University of Florida, Gainesville, FL 32611.

The use of trade names in this publication is solely for the purpose of providing specific information. UF/IFAS does not guarantee or warranty the products named, and references to them in this publication do not signify our approval to the exclusion of other products of suitable composition. All herbicides should be used in accordance with directions on the manufacturer's label.

The Institute of Food and Agricultural Sciences (IFAS) is an Equal Opportunity Institution authorized to provide research, educational information and other services only to individuals and institutions that function with non-discrimination with respect to race, creed, color, religion, age, disability, sex, sexual orientation, marital status, national origin, political opinions or affiliations. U.S. Department of Agriculture, Cooperative Extension Service, University of Florida, IFAS, Florida A\&M University Cooperative Extension Program, and Boards of County Commissioners Cooperating. Nick T. Place, Dean 
succulent and hairy (Figure 2). Young branches have lines of minute hairs proximal to the leaf stalk. Small pairs of leaf-like appendages (stipules) are present and hairless. Leaves are simple, entire, and hairless on both sides, with unequal pairs sub-opposite to opposite along the stem. Flowers are solitary, axillary, and stalkless (Figure 3). Flowers are pink to rose-purple within, green externally, and hood-like, with a short horn near the tip. The fruit is a capsule with 1-5 seeds when mature. Seeds are small, kidney-shaped, dull reddish-brown to black, and ridged. Horse purslane has a taproot system with fibrous hairs.

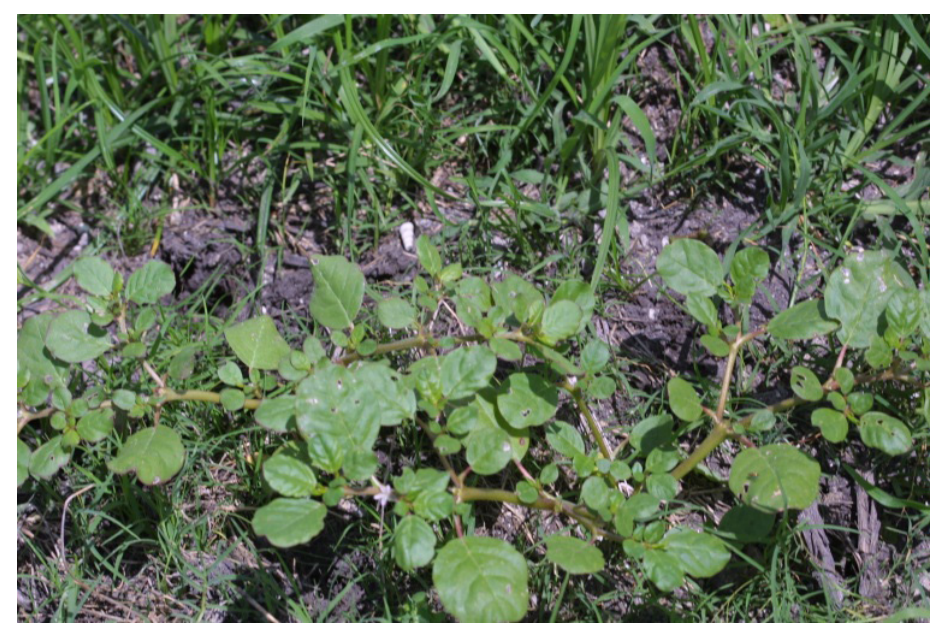

Figure 2. Prostrate and branched horse purslane.

Credits: D. C. Odero

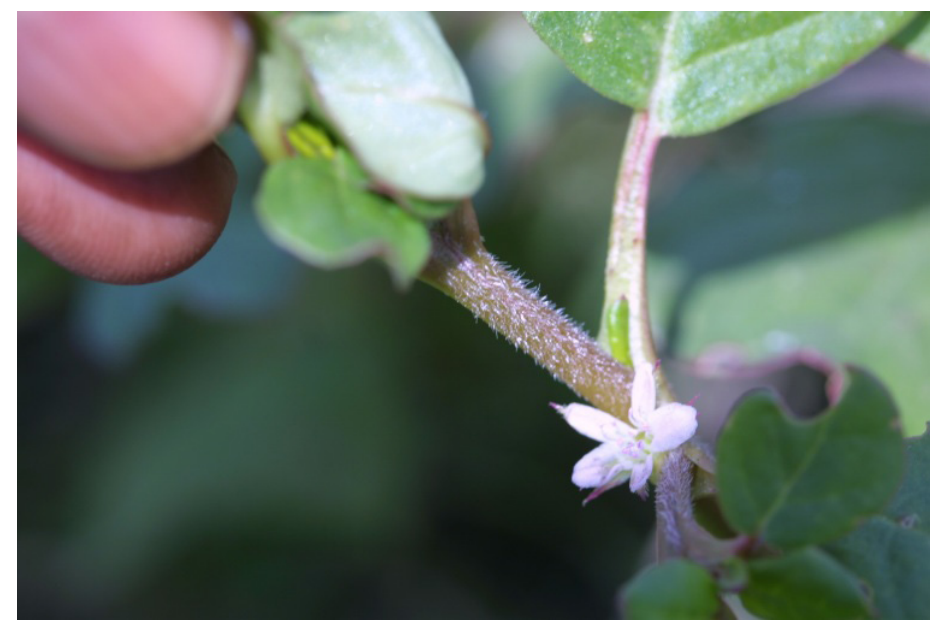

Figure 3. Hairy branch and flower of horse purslane.

Credits: D. C. Odero

Horse purslane has exclusive vegetative growth for 35-40 days after emergence, and then both the vegetative growth and reproductive growth continue simultaneously. Horse purslane seeds germinate at $68^{\circ} \mathrm{F}-113^{\circ} \mathrm{F}$, with maximum germination occurring at $95^{\circ} \mathrm{F}$ (Balyan and Bhan 1986). Seeds do not exhibit dormancy and will emerge from 2/5-inch deep (Balyan and Bhan 1986). However, seed emergence will gradually decline with increasing soil depth.
The special identifying features of horse purslane include opposite leaves in pairs of unequal size and pink to rose flowers (SWSS 1993).

\section{Control Recommendations}

Trifloxysulfuron (Envoke) is the only herbicide labeled for selective control of horse purslane in sugarcane. It can be applied pre-spiking to plant cane at the rate of 0.3 ounce per acre. Postemergence over-the-top applications to stubble (ratoon) cane can be made at the rate of 0.3 ounce per acre to cane up to 24 inches tall. Trifloxysulfuron can also be applied post-directed to plant or stubble cane at the rate of $0.3-0.6$ ounce per acre to cane that is 24 inches tall through layby. A nonionic surfactant at $0.25 \% \mathrm{v} / \mathrm{v}$ (1 quart per 100 gallons) must be tank-mixed with Envoke. Cultivation can also control horse purslane in row middles.

\section{Common Purslane}

Common purslane (Portulaca oleracea) is a prostrate, fleshy, succulent, annual weed in the Portulacaceae (purslane) family (Uva, Neil, and DiTomaso 1997). Originally native to Western Asia, it is widely distributed throughout most of the United States, where it is most abundant in the Northeast and least common in the Pacific Northwest (USDA-NRCS 2012). Common purslane is widely distributed throughout Florida where it grows in almost all cultivated fields, and non-crop and disturbed areas. The thick succulent leaves, stems, and roots of common purslane enable it to absorb and store water and withstand dry soil conditions. Common purslane is a very aggressive weed listed as one of the ten most noxious weeds worldwide.

\section{Seedling}

Seedlings are erect (Figure 4) but soon become prostrate. Cotyledons are linear, green or maroon on the top surface, and maroon on the lower surface. Young leaves are succulent and colored green on the upper surface, but maroon-tinged or maroon on the lower surface. The leaves are placed opposite or nearly opposite each other with each succeeding pair $90^{\circ}$ from the preceding pair. The oblong leaf blades taper toward the base and are broadest and rounded at the apex. Leaf stalks are absent. Stems are succulent, prostrate, green on the younger portions, and maroon in the older portions.

\section{Mature Plant}

The hairless stems are much-branched, prostrate, and succulent. They are usually colored purplish-red and grow from 4 to 20 inches long (Figure 5). Leaves are thick and fleshy with smooth margins. They grow alternate or nearly 


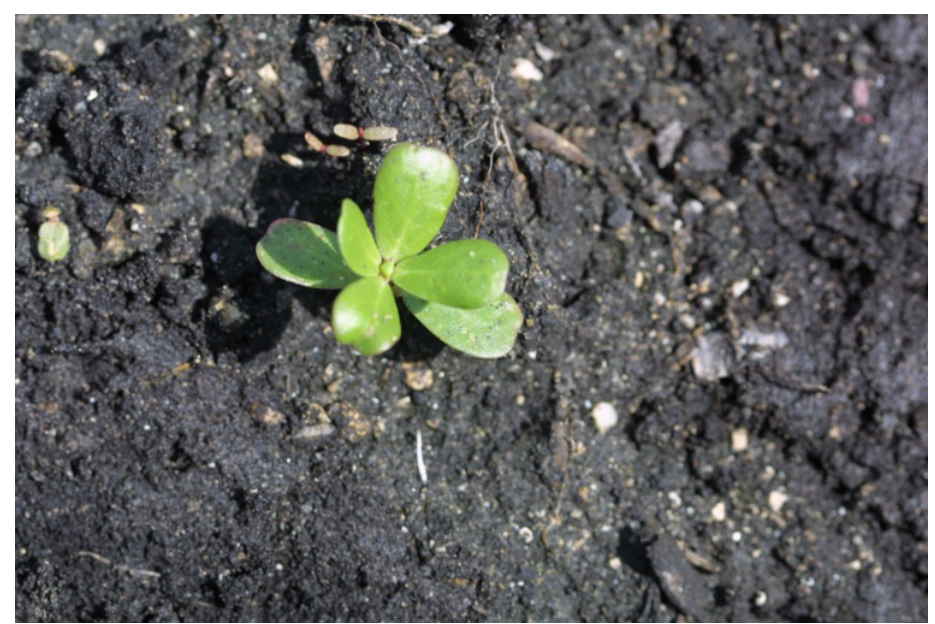

Figure 4. Seedling of common purslane.

Credits: D. C. Odero

opposite, reaching 2/5-1 inch in length. Leaf blades are wedge-shaped, rounded at the tip, narrowed at the base, and flattened. Leaf stalks are absent, and small pairs of leaflike appendages (stipules) may be present as soft bristles.

Common purslane has a thick, much-branched, fleshy taproot with many fibrous secondary roots. Flowers are yellow, $1 / 5-2 / 5$-inch in diameter, and solitary in the leaf axils or clustered at the end of the branches (Figure 6). The flowers open only when it is sunny. The fruit is a round capsule that splits open around the middle to release seeds. The tiny, black or dark brown seeds are slightly glossy, flattened, and rounded to kidney-shaped, with rounded bumps on the surface. Common purslane reproduces primarily by seeds and stem fragments that root at the nodes. Seeds can have a long dormancy period that can exceed three years. Germination occurs at $68^{\circ} \mathrm{F}-104^{\circ} \mathrm{F}$ and is augmented by abrasion of seeds (Vengris, Duann, and Stacewicz-Sapuncakis 1972). The greatest emergence occurs when seeds are on the soil surface and progressively declines as depth increases (Vengris, Duann, and Stacewicz-Sapuncakis 1972). Germination does not occur at depths greater than 1 inch.

The special identifying features of common purslane are its succulent leaves and stems, small yellow flowers in leaf axils, and alternate leaves (SWSS 1993).

\section{Control Recommendations}

Common purslane can be controlled preemergence with metribuzin applied at 1 1/3-2 2/3 ounces per acre. Postemergence application of 2,4-D amine at 1 quart per acre or a tank-mix of Callisto (mesotrione) at 3 fluid ounces and atrazine at 1 pint per acre will provide control of common purslane. Cultivation can also control common purslane in row middles; however, stem fragments can root at the nodes if not completely desiccated following cultivation.

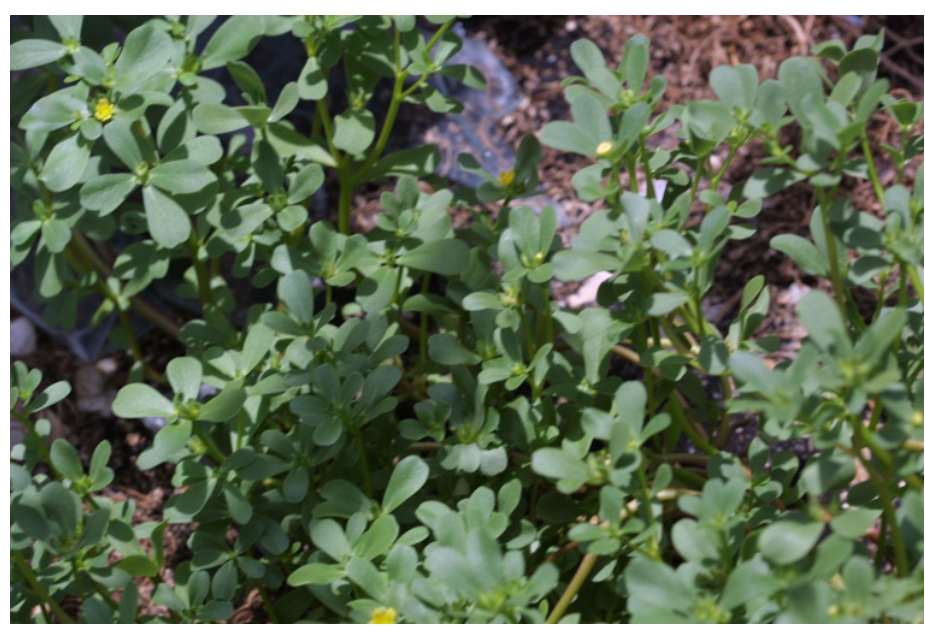

Figure 5. Branched prostrate common purslane. Credits: D. C. Odero

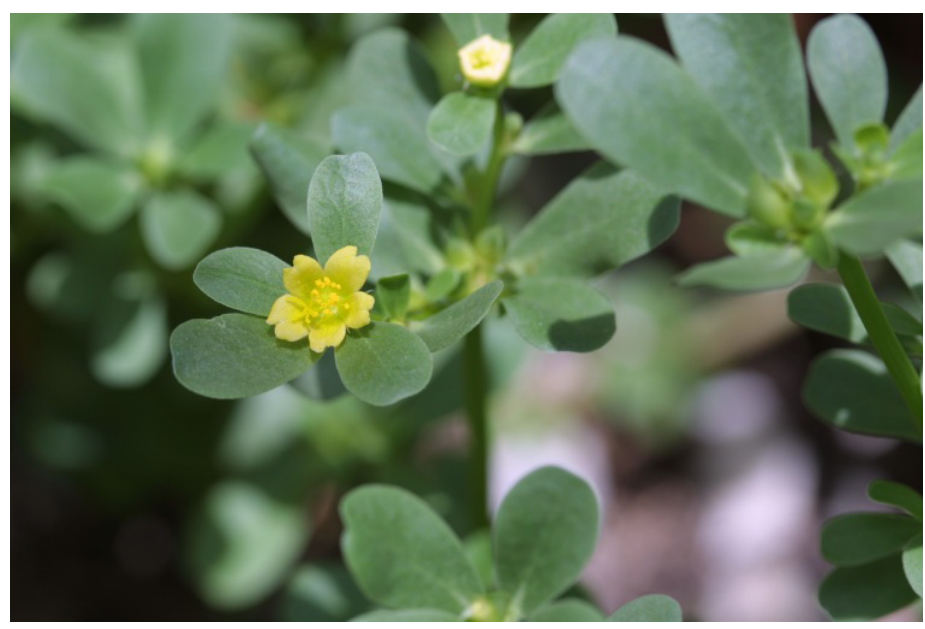

Figure 6. Flower of common purslane.

Credits: D. C. Odero

\section{References}

Balyan, R.S., and V.M. Bhan. 1986. "Emergence, Growth, and Reproduction of Horse Purslane (Trianthema portulacastrum) as Influenced by Environmental Conditions." Weed Science 34: 516-9.

Southern Weed Science Society (SWSS). 1993. Weed Identification Guide. Champaign: Southern Weed Science Society.

"Trianthema portulacastrum L. - AIZOA-

CEAE - Dicotyledon.” Accessed November 10, 2012.

http://www.oswaldasia.org/species/t/trtpo/trtpo_en.html.

United States Department of Agriculture, Natural Resources Conservation Service (USDA-NRCS). 2012. "Portulaca oleracea L. little hogweed.” Accessed November 10, 2012. http://plants.usda.gov/java/profile?symbol=POOL. 
USDA-NRCS. 2012. "Trianthema portulacastrum L. desert horsepurslane.” Accessed November 10, 2012.

http://plants.usda.gov/java/profile?symbol=TRPO2.

Uva, R.H., J.C. Neil, and J.M. DiTomaso. 1997. Weeds of the Northeast. Ithaca: Cornell University Press.

Vengris, J., S. Duann, and M. Stacewicz-Sapuncakis. 1972. "Life History Studies as Related to Weed Control in the Northeast. 7 - Common Purslane." Northeast Regional Publication. Research Bulletin 598. Amherst, MA: The University of Massachusetts, Amherst, College of Food and Natural Resources, Agricultural Experiment Station. 